\title{
Analysis Of Human Resource Competency, Internal Control System, Quality Of Financial Statements and Application Of Government Accounting Standards To Accountability Of Performance Of Government Agencies In Pegunungan Bintang Regency
}

\author{
Ramasoyan, Pascalina Van Sweet Sesa, Kurniawan Patma, Rudiawie Larasati \\ Cenderawasih University, Indonesia \\ Email: ramasoyan.al@gmail.com, pascalinasesa@gmail.com, patmakurniawan@gmail.com, \\ ademaularasati@yahoo.co.id
}

\begin{tabular}{l} 
ARTICLE INFO \\
\hline Received \\
23 Juny 2021 \\
Revision \\
1 July 2021 \\
Approved \\
10 July 2021 \\
\hline Keywords: \\
hr competencies \\
internal control system \\
quality of financial \\
statements \\
implementation of \\
government \\
accounting standards \\
government agency \\
performance \\
accountability
\end{tabular}

ARTICLE INFO

\section{ABSTRACT}

Regional device organization (OPD) of Pegunungan Bintang Regency. The internal control system has a significant effect on the accountability of the performance of government agencies in the Purpose Organization in this study to know and analyze the influence of human resource competence, the influence of internal control systems influence the quality of financial statements, the implementation of government accounting standards on government performance accountability, and silmultan to the accountability of government agencies performance. The population in this study is employees of the Regional Device Organization (OPD) Of Pegunungan Bintang District who routinely carry out inspection tasks and have a minimum educational background diploma 3 (D3) Accounting, have attended JFA training (Auditor Functional Department) and have a minimum work experience of 1 Year. The analysis techniques used are multiple regression analysis techniques to process and discuss the data that has been obtained and test the proposed hypothesis. The results of the analysis are known that human resources competency variables have a significant influence on the accountability of the performance of government agencies Regional Devices (OPD) Gunung Bintang District,the quality of financial statements have a significant effect on the accountability of the performance of government agencies in the Regional Device Organization (OPD) Gunung Bintang District.

\section{INTRODUCTION}

Accountability is believed to be able to change the condition of government that can not provide public services properly towards a democratic governance order. The implementation of an accountable government will have the support of the public. There is public trust in what is

\footnotetext{
How to cite:

Ramasoyan, Pascalina Van Sweet Sesa, Kurniawan Patma, Rudiawie Larasati (2021) Analysis Of Human Resource Competency, Internal Control System, Quality Of Financial Statements and Application Of Government Accounting Standards To Accountability Of Performance Of Government Agencies In Pegunungan Bintang Regency. Jurnal of Social Science 2(4).

E-ISSN: https://doi.org/10.46799/jss.v2i4.188

Published by: 2721-5202 Ridwan Institute
} 
organized, planned, and implemented by public-oriented programs. On the part of the organizers, accountability reflects the government's commitment to serving the public (Riantiarno \& Azlina, 2011).

Accountability of the performance of government agencies is as an obligation of individuals or rulers entrusted to manage public resources and concerned with them in order to be able to answer matters related to accountability as an instrument for control activities, especially in the achievement of work in public services. Performance accountability is influenced by many things, including the application of public accounting, the quality of laws and regulations and compliance with regulations the quality of the financial.

The Government of Pegunungan Bintang Regency is a newly developed regency in Papua Province centered in Oksibil, Gunung Bintang Regency is a regency of Jayawijaya Regency. At the beginning of the expansion of Pegunungan Bintang Regency for the first 3 years there has been no financial reporting submitted by Pegunungan Bintang Regency to the Audit Board of Finance (BPK) but for the last 14 years Pegunungan Bintang District has submitted financial statements and in 2019 has obtained a fair opinion with the exception (WDP) of government financial statements and no significant irregularities can affect the fairness of financial statements, with the exception of reasonable opinion (WDP) on the government's financial laoran is very necessary this research is carried out in Pegunungan Bintang District (BPK report of Papua Province may 2019).

The financial report of the Government of Pegunungan Bintang Regency received a fair opinion with the exception (WDP) so that there are still issues to be considered, namely Control, Recording and Control of assets has not been significant. Based on the above background, the titles that are attached in this study are The Influence of Human Resources Competency, Internal Control System, Quality of Financial Statements and Application of Government Accounting Standards to Performance Accountability of Government Agencies in Pegunungan Bintang Regency.

Agency theory has the main principle in the form of working relationship between two parties, namely the party that gives authority (principal) with the party that receives authority (agency) in a form of cooperation called the "nexus of contract". The Agent acts as a contracted party by the principal to work in accordance with the interests of the principal. Agency theory can be interpreted where there is a relationship between two parties, namely the principal and the agent who is ordered for a job or service in a contract on behalf of the principal and gives full freedom to the agent in determining policies that are beneficial to principal (Jensen \& Meckling, 1976). (Jensen \& Meckling, 1976) explain that there is a difference of interest between the principal and the agent, so that the agent does not always follow the principal's wishes.

(Udoyono, 2012) Accountability is the obligation to present and report on the conditions of accountability in terms of monitoring all actions, in this case actions aimed at achieving the objectives. Performance benchmarks or accountability indicators are the obligation of individuals and organizations to explain the results of through objective measurements where possible. In this study, the financial services are considered qualified if transparent and accountable.

Performance accountability in accordance with LAN is the obligation to give accountability or answer and explain the performance and actions of an organization's legal entity/leader to the party that has the right or obligation to hold accountable or information in all government agencies both central and local government, departments or state agencies must understand their responsibilities in accordance with their main duties and responsibilities.

Human resource competencies, (Halim, 2010) describe the ability of human resources to fulfill a given task and responsibility with education, training and experience. Human resources are the most important organizational element. Therefore, human resources must be managed in the best way possible so that they can contribute as well as possible to the achievement of organizational goals. The relationship between the officer who receives authority from the principal to carry out the duties in accordance with the interests of the principal is an agency 
relationship, so the agent must be responsible to the principal.

Government Regulation No. 60 of 2008 stipulates that internal control is an integral process of activities and actions carried out on an ongoing basis to ensure sufficient trust in achieving organizational objectives through effective and efficient actions, reliable financial reports, safeguarding of state assets, actions and compliance with laws and regulations. SPI is a controlling activity especially for the management of information systems, which aims to ensure the accuracy and completeness of information.

Internal control according to (Commission, 1994) is a process influenced by the board of directors, management and other personnel designed to provide sufficient confidence in achieving the effectiveness and operational efficiency of the entity, reliability of financial statements and compliance with applicable laws. The definition is the same as the definition of internal control in Government Regulation number 8 of 2006, which is a process influenced by management, designed to provide sufficient confidence in achieving efficiency, effectiveness, compliance with applicable laws and applicable reporting, and reliability of the presentation of financial statements.

\section{METHOD}

\section{Research Location}

This research will be conducted at 13 Regional Device Organizations (OPD) in Pegunungan Bintang Regency, namely:

Office of Revenue, Financial and Asset Management, Inspectorate of Pegunungan Bintang District, Regional Staffing Agency (BKD) of Pegunungan Bintang Regency, BPSDM Pegununngan Bintang Regency, Population and Civil Registry Office, Social Service, Public Works Office, Health Office, BPMPK, Cultural and Tourism Office, Linmas Kesbangkol Agency, Agriculture, Fisheries, and Livestock Office,BAPPEDA.

\section{Population and Samples}

Sampling using Proposive Sampling method is sampling according to the criteria set in a data retrieval. The criteria used in sampling are as follows:
a. Star Mountains Regional Device Organization (OPD).

b. Employees who routinely carry out inspection duties and have a minimum educational background diploma 3 (D3) Accounting.

c. Has attended JFA training (Auditor Functional Department).

d. Have a minimum work experience of 1 Year.

\section{Types and Data Sources}

In this study the authors used quantitative research in the form of questionnaires, because the data obtained later in the form of numbers. From the figures obtained will be further analyzed in the analysis of data. This research consists of 5 variables, namely Human Resource Competency, Quality of Financial Statements, Internal Control System, Application of Government Accounting Standards as free variables (independent), while Performance Accountability of Government Agencies as dependent variables.

The data used in this study is primary data, primary data is data obtained by researchers directly by conducting interviews and also disseminating questionnaire questionnaires. The methods and tools used in this method of data collection are questionnaires, observations, and literary research (literature).

\section{Measurement Methods and Tools}

This research uses quantitative analysis method. As explained by (Latjandu, Kalangi, \& Tinangon, 2016) that quantitative method can be interpreted as a research method based on philosophy positivism, used to research on a particular population or sample, sampling techniques are generally done purposively, data collection using research instruments, data baseisis quantitative or statistical with the aim to test the hypothesis that has been set. Data Analysis Techniques In this study, the analysis techniques used are multiple linear analysis with the help of SPSS Statistics 16.0 software. The questionnaire used to measure dependent variables is a questionnaire developed from previous researchers that relates to these variables.

\section{Data Analysis Methods}

a. Multiple Regression Analysts 
This analysis uses equations to analyze the influence between independent variables (X1-X4) on variables dependents $(Y)$. The multiple linear regression models in this study are:

$Y=a+b 1 X 1+b 2 X 2+b 3 X 3+b X 4$

$+\mathrm{e}$

information:

Y : Government Agency Performance Accountability

X1 : Human Resources Competency

X2 : Internal Control System

X3 : Financial Report Quality

X4 : Implementation of Government Accounting Standards

A: Konstan

b1 : ... b3: Koefisien regresi

e: Error

b. Data Instrument Test

Data Instrument Test used in this study is Validity Test and ReliabilityTest.

c. Classic Assumption Test

The Classic Assumption Test used in this study is multicolinearity test, heteroskedastisity test and normality test, and Autocorrelationtest.

d. Regression Results

The coefficient of determination (R2) is used to measure how capable the model is of explaining or describing a variation of a dependent variable. The coefficient of determination is between 0 and 1 . When the value of R2 is small it means that the ability of independent variables $(X)$ to describe dependent variable variations $(Y)$ is very limited. Likewise, the large R2 value is the ability of independent variables in describing variations of large dependent variables Ghozali, (2013).

The $F$ test is used to test whether the regression model to be studied has significant or insignificant value. In this test the following hypotheses were used:

$\mathrm{HO}: \beta 1=\beta 2=\beta 3=0$

$\mathrm{Ha}: \beta 1 \neq \beta 2 \neq \beta 3 \neq 0$

F-count $=$ R2/ (k-1): (1-R2)/(n-k)

Where : R2 = Coefficient of determination

$\mathrm{K}=$ Estimated number of parameters including constants

$\mathrm{N}=$ Number of observations

- If the $F$ value is significant < (a) significance rate of $5 \%$ then the regression model has a good level of model conformity.

- If the $F$ value is significant $\geq(a)$ significance level of $5 \%$ then the regression model has a bad level of model conformity.

Test $t$-use to test the significance of the relationship between variables $X$ and $Y$, whether independent variables $(\mathrm{X})$ actually affect dependent (Y) variables separately or partially Ghozali, (2013). This test is used to test the hypotheses of human resource competency variables, the quality of the finance implementation of government accounting standards and internal control systems. The hypotheses used in this test are:

Ho: Independent variables (X) have no effect on dependent variables (Y).

Ha: Independent variables (X) have an influence on dependent variables $(Y)$.

\section{RESULTS AND DISCUSSION}

\section{A. Result}

1. Questionnaire Distribution Recapitulation

Table 1

Questionnair Distribution Recapitulation

\begin{tabular}{lcc}
\hline Distributed questionnaires & 80 Respond & $100 \%$ \\
\hline Incomplete questionnaire & 9 & $11,25 \%$ \\
\hline Questionnaires that fall to no & 14 & $17,5 \%$ \\
\hline Answered & & \\
\hline $\begin{array}{l}\text { Questionnaires that can be } \\
\text { processed }\end{array}$ & 57 & $71,25 \%$ \\
\hline
\end{tabular}


Based on the table 1, it can be concluded that out of the 80 questionnaires that have been disseminated. There were 9 questionnaires returned with incomplete conditions and 14 questionnaires that were not answered, thus qualified questionnaires and can be processed as many as 57 questionnaires. So that questionnaires that qualified this study as many as $\mathbf{5 7}$ questionnaires or $71.25 \%$.

\section{Data Analysis}

Table 2

Descriptive Statistics Table

\begin{tabular}{|c|c|c|c|c|c|c|c|c|}
\hline & $\mathbf{N}$ & Range & Minimum & Maximum & Mean & Std.Deviation & Variance & Variance \\
\hline & Statistic & Statistic & Statistic & Statistic & Statistic & Std.Error & Statistic & Statistic \\
\hline $\begin{array}{c}\text { Competence } \\
\text { SDM }\end{array}$ & 57 & 13.00 & 27.00 & 40.00 & 31.9298 & 41575 & 3.13881 & 9.852 \\
\hline SPI & 57 & 14.00 & 21.00 & 35.00 & 27.7193 & 39638 & 2.99258 & 8.956 \\
\hline PSAP & 57 & 31.00 & 29.00 & 60.00 & 48.0877 & 83781 & 6.32535 & 40.010 \\
\hline AKIP & 57 & 5.00 & 10.00 & 15.00 & 12.3860 & 16932 & 1.27831 & 1.634 \\
\hline $\begin{array}{c}\text { Valid N } \\
\text { (listwise) }\end{array}$ & 57 & & & & & & & \\
\hline
\end{tabular}

Source: Data processed, 2020.

Based on the table 2, shows that human resource competence has a theoretical range between 27.00 to 40.00 with an average value of 31.9298 and standard deviation of 3.13881. In the internal control system variables have a theoretical range between 21.00 to 35.00 with an average value of 27.7193 and standard deviation of 2.99258. The quality of financial statements has a theoretical range between 14.00 to 30.00 with an average value of 24.3333 and standard deviation of 3.59729. the implementation of government accounting standards has a theoretical range between 29.00 to 60.00 with an average value of 48.0877 and a standard deviation of 6.32535 . accountability performance of government agencies has a theoretical range between 10.00 to 15.00 with an average value of 12.3860 and standard deviation of 1,634 .

\section{Data Quality Test Results}

\section{Validity Test Results}

Validity tests were conducted with pearson correlation to test the correlation of each question item score against the variable's total score.

Table 3

Hr Competency Variable Validity Test $\left(X^{1}\right)$

\begin{tabular}{ccccc}
\hline No & variable & $\begin{array}{c}\text { Person } \\
\text { Corelation }\end{array}$ & $\begin{array}{c}\text { Coefficient of } \\
\text { Significance }\end{array}$ & conclusion \\
\hline 1. & $\begin{array}{c}\text { HR Competency } \\
\text { X1: }\end{array}$ & & & \\
\hline $\mathrm{X} 1.1$ & 0,579 & 0,000 & Valid \\
\hline $\mathrm{X} 1.2$ & 0,735 & 0,000 & Valid \\
\hline $\mathrm{X} 1.3$ & 0,606 & 0,000 & Valid \\
\hline
\end{tabular}




\begin{tabular}{cccc}
\hline X1.4 & 0,589 & 0,005 & Valid \\
\hline $\mathrm{X} 1.5$ & 0,593 & 0,000 & Valid \\
\hline $\mathrm{X} 1.6$ & 0,401 & 0,002 & Valid \\
\hline $\mathrm{X} 1.7$ & 0,568 & 0,000 & Valid \\
\hline & 0,657 & 0,000 & Valid \\
\hline
\end{tabular}

Source: Data processed, 2020

Based on the table 3 shows that each question item of the HR competency variable (X1) shows a significant result below 0.05 .

Table 4

Internal Control System Variable Validity Test $\left(X^{2}\right)$

\begin{tabular}{ccccc}
\hline No & Variabel & $\begin{array}{c}\text { Person } \\
\text { Corelation }\end{array}$ & $\begin{array}{c}\text { Coefficient of } \\
\text { Significance }\end{array}$ & conclusion \\
\hline 2. & SPI ( $\left.\mathbf{X}^{2}\right):$ & & & \\
\hline & $\mathrm{X}^{2} .1$ & 0,760 & 0,000 & Valid \\
\hline $\mathrm{X}^{2} .2$ & 0,748 & 0,000 & Valid \\
\hline $\mathrm{X}^{2} .3$ & 0,520 & 0,000 & Valid \\
\hline $\mathrm{X}^{2} .4$ & 0,532 & 0,000 & Valid \\
\hline $\mathrm{X}^{2} .5$ & 0,660 & 0,000 & Valid \\
\hline $\mathrm{X}^{2} .6$ & 0,387 & 0,003 & Valid \\
\hline $\mathrm{X}^{2} .7$ & 0,757 & 0,000 & Valid \\
\hline
\end{tabular}

Source: Data processed, 2020.

Based on the table 4 shows that each question item of the internal control system variable (X2) shows a significant result below 0.05 .

Table 5

Financial Report Quality Variable Validity Test $\left(\mathbf{X}^{3}\right)$

\begin{tabular}{ccccc}
\hline No & Variabel & $\begin{array}{c}\text { Person } \\
\text { Corelation }\end{array}$ & $\begin{array}{c}\text { coefficient } \\
\text { Significance }\end{array}$ & conclusion \\
\hline 3. & KLK X X: & & & \\
\hline & $X_{3.1}$ & 0,650 & 0,000 & Valid \\
\hline$X_{3.2}$ & 0,868 & 0,000 & Valid \\
\hline$X_{3.3}$ & 0,695 & 0,000 & Valid \\
\hline$X_{3.4}$ & 0,726 & 0,000 & Valid \\
\hline$X_{3.5}$ & 0,823 & 0,000 & Valid \\
\hline$X_{3.6}$ & 0,780 & 0,000 & Valid \\
\hline
\end{tabular}

Source: Data processed, 2020.

Based on the table 5 shows that each question item of the financial report quality variable (X3) shows a significant result below 0.05 .

Table 6

Implementation Variable Validity Test

Government Accounting Standards $\left(\mathrm{X}_{4}\right)$

\begin{tabular}{ccccc}
\hline No & Variabel & $\begin{array}{c}\text { Person } \\
\text { Corelation }\end{array}$ & $\begin{array}{c}\text { coefficient } \\
\text { Significance }\end{array}$ & conclusion \\
\hline 4. & $\begin{array}{c}\text { PSAP } \\
\left(\mathbf{X}_{4}\right):\end{array}$ & & & \\
\hline & $\mathrm{X}_{4.1}$ & 0,635 & 0,000 & Valid \\
\hline & $\mathrm{X}_{4.2}$ & 0,841 & 0,000 & Valid \\
\hline
\end{tabular}




\begin{tabular}{cccc}
\hline $\mathrm{X}_{4.3}$ & 0,724 & 0,000 & Valid \\
\hline $\mathrm{X}_{4.4}$ & 0,678 & 0,000 & Valid \\
\hline $\mathrm{X}_{4.5}$ & 0,783 & 0,000 & Valid \\
\hline $\mathrm{X}_{4.6}$ & 0,705 & 0,000 & Valid \\
\hline $\mathrm{X}_{4.7}$ & 0,855 & 0,000 & Valid \\
\hline $\mathrm{X}_{4.8}$ & 0,367 & 0,005 & Valid \\
\hline $\mathrm{X}_{4.9}$ & 0,598 & 0,000 & Valid \\
\hline $\mathrm{X}_{4.10}$ & 0,685 & 0,000 & Valid \\
\hline $\mathrm{X}_{4.11}$ & 0,503 & 0,000 & Valid \\
\hline $\mathrm{X}_{4.12}$ & 0,664 & 0,000 & Valid
\end{tabular}

Source: Data processed, 2020.

Based on the table 6 shows that each question item of the government accounting standard implementation variable $(\mathrm{X} 4)$ shows a significant result below 0.05 .

Table 7

Government Agency Performance Accountability Variable Validity Test (Y)

\begin{tabular}{ccccc}
\hline No & Variabel & $\begin{array}{c}\text { Person } \\
\text { Corelation }\end{array}$ & $\begin{array}{c}\text { coefficient } \\
\text { Significance }\end{array}$ & conclusion \\
\hline 5. & $\begin{array}{c}\text { AKIP } \\
(\mathrm{Y}):\end{array}$ & & & \\
\hline & $\mathrm{X}_{4.1} 1$ & 0,743 & 0,000 & Valid \\
\hline $\mathrm{X}_{4 .} 2$ & 0,792 & 0,000 & Valid \\
\hline $\mathrm{X}_{4.3} 3$ & 0,621 & 0,000 & Valid \\
\hline
\end{tabular}

Source: Data processed, 2020.

Based on the table 7 shows that each question item of the government agency performance accountability variable $(Y)$ showed a significant result below 0.05 .
Reliability test is used to determine the reliable level of a measuring instrument using cronbach alpha formula. A construct or reliable is said to be reliable if it provides an alpha cronbach value of $>0.60$ (Ghozali, 2006).

\section{a. Reliability Test Results}

Table 8

Reliability Test

\begin{tabular}{lcc}
\hline \multicolumn{1}{c}{ Variable Research } & $\begin{array}{c}\text { Cronbach } \\
\text { Alpha }\end{array}$ & information \\
\hline HR Competencies & 0,744 & Reliabel \\
\hline $\begin{array}{l}\text { Internal Control } \\
\text { System }\end{array}$ & 0,754 & Reliabel \\
\hline $\begin{array}{l}\text { Financial Report } \\
\text { Quality }\end{array}$ & 0,790 & Reliabel \\
\hline $\begin{array}{l}\text { Implementation of } \\
\text { Government } \\
\text { Accounting Standards }\end{array}$ & 0,762 & Reliabel \\
\hline $\begin{array}{l}\text { Government Agency } \\
\text { Performance } \\
\text { Accountability }\end{array}$ & 0,787 & Reliabel \\
\hline \multicolumn{1}{c}{ Source: Data processed, 2020} &
\end{tabular}

Source: Data processed, 2020. 

Based on the table 8 from each variable competency competency HR, internal control system, quality of financial statements, application of government accounting standards and performance accountability of government agencies has a value of Cronbach Alpha $>0.60$, thus the data used reliable and can be continued to conduct multiple linear tests.

\section{Classic Assumption Test}

\section{a. Normality Test}

Normality tests are used to test whether the data used is normally distributed. Good data is to have a normal distribution. Testing was conducted using the normal curve of the probabilty plot, provided that the dots on the chart spread and squeezed following around diagonal line then the data used is normally distributed. If on the table test of normality using Kolmogorov-Smirnov sig value >
0.05 , then the data is normally distributed, (Ghozali, 2006).

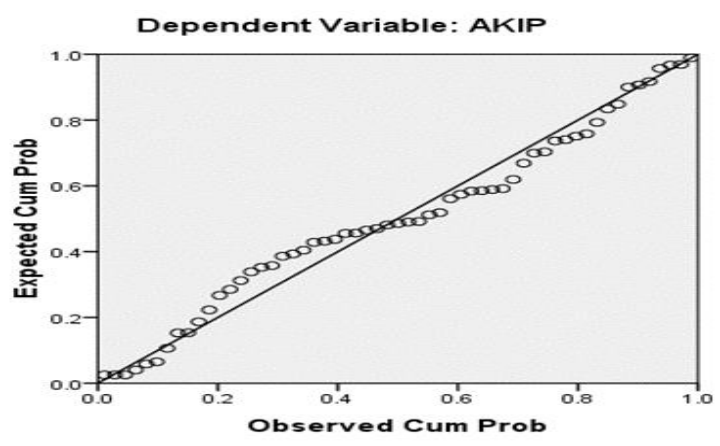

Source: Data processed, 2020.

The result of the normal probability plot curve shows that the points on the chart appear to stick and follow the diagonal line, so that based on the normal curve of the probability plot, the data used is normally distributed.

Table 9

Kolmogrof Smirnov Test

\begin{tabular}{ccc}
\hline & & $\begin{array}{c}\text { Unstandardized } \\
\text { Residual }\end{array}$ \\
\hline $\mathrm{N}$ & Mean & 57 \\
\hline Normal Parameters & Std. Deviation & .0000000 \\
\hline $\begin{array}{c}\text { Most Extreme } \\
\text { Differences }\end{array}$ & Absolute & .08856347 \\
\hline & Positive & .089 \\
\hline & Negative & -.087 \\
\hline Kolmogorov-Smirnov Z & & .674 \\
\hline Asymp. Sig. (2-tailed) & & .754 \\
\hline
\end{tabular}

a. Test distribution is Normal.

Source: Data Processed 2020

In the table 9, the Kolomorov Smirnov test showed that the residual data obtained followed the normal distribution, based on the output results showed a significant Kolmogorov-Smirnov value at 0.754 $>0.05$. Thus, residual data is normally distributed and the regression model has met the assumptions of normality.

b. Multikololinearity Test
Multicolinearity is seen from the value of toleance and variance inflation factor (VIF). Tolerance measures selected independent variability that other independent variables do not describe. So the tolance value is low there with a high VIF value. The common cutoff value used to indicate multiconearity is a tolerance value < 0.1 or equal to the VIF value $>10$ (Ghozali, 2006). 
Table 10

Multicolinearity Test

\begin{tabular}{lcc}
\hline \multirow{2}{*}{ Model } & \multicolumn{2}{c}{$\begin{array}{c}\text { Collinearity } \\
\text { Statistics }\end{array}$} \\
\cline { 2 - 3 } & Tolerance & VIF \\
\hline 1 (Constant) & & \\
\hline HR Competencies & .127 & 7.879 \\
\hline SPI & .139 & 7.212 \\
\hline KLK & .152 & 6.194 \\
\hline PSAP & .142 & 4.025 \\
\hline
\end{tabular}

a. Dependent Variable : Investment Interest Source: Data processed, 2020.

Based on Table 10 which is the result of multicolinearity, can be seen the magnitude of each independent variable obtained greater than 0.1 and VIF (variance inflation factor) smaller than 10, then from the results of toleance and VIF values, can be concluded that there are no symptoms of multicolinearity in the regression of this study.

c. Heterokedastisity Test

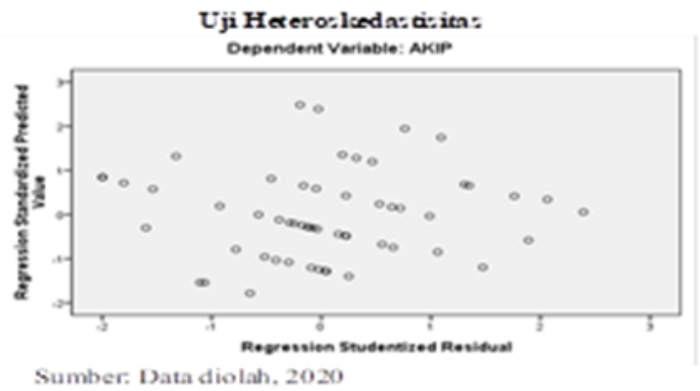

Based on the picture above shows that the dots spread randomly then it can be concluded that there is no heterokedastisitas in this regression model.

Table 11

Glejser Test Results

\begin{tabular}{|c|c|c|c|c|c|c|}
\hline & \multirow[b]{2}{*}{ Model } & \multicolumn{2}{|c|}{ Unstandardized } & \multirow{2}{*}{$\begin{array}{c}\text { Standardized } \\
\text { Beta }\end{array}$} & \multirow[b]{2}{*}{$\mathbf{t}$} & \multirow[b]{2}{*}{ Sig. } \\
\hline & & B & $\begin{array}{l}\text { Std. } \\
\text { Error }\end{array}$ & & & \\
\hline 1 & (Constant) & -1.507 & 1.590 & & -.948 & .356 \\
\hline & $\begin{array}{c}\text { HR } \\
\text { Competencies }\end{array}$ & -.002 & .002 & -1.097 & -.737 & .471 \\
\hline & SPI & .068 & .070 & .866 & .971 & .344 \\
\hline & KLK & -.001 & .000 & -.060 & -.055 & .957 \\
\hline & PSAP & .012 & .027 & .713 & .552 & .588 \\
\hline
\end{tabular}

a. Dependent Variable: ABSUi

Source: Data processed, 2020.

If the significance value ( $\mathrm{Sig}$ )

$>0.05$ then there is no symptom of
Heteroskedastisitas.If the value of significance $(\mathrm{Sig})<0.05$ then 
heteroskedastisitas occurs. Based on the table above can be known not to occur heterokedastisitas, this is demonstrated by the value of the significance of human resources competency variables, internal data generation system, quality of financial statements and the application of government accounting standards that have more than 0.05 .

\section{Multiple Linear Analysis}

Multiple linear analysis is used to determine the magnitude of the influence of HR competencies, internal control systems, the quality of financial statements, and the application of government accounting standards to the accountability of government agencies' performance. Summary of regression analysis results can be seen in the followingtable:

Table 11

Regression Analysis Results Summary

\begin{tabular}{ccccc}
\hline Variabel & $\begin{array}{c}\text { coefficient } \\
\text { B }\end{array}$ & Thitung & Significant & information \\
\hline Constant & 1,423 & & & \\
\hline HR Competencies & 0,331 & 4,115 & 0,000 & Significant \\
\hline SPI & 0,167 & 2,064 & 0,044 & Significant \\
\hline KLK & 0,284 & 2,590 & 0,012 & Significant \\
\hline PSAP & 0,231 & 3,319 & 0,002 & Significant \\
\hline a & $=0.05$ & & & \\
\hline Coefficient of & $=.862$ & & & \\
\hline Determination $\left(\mathrm{R}^{2}\right)$ & $=.743$ & & & \\
\hline F - count & $=37,503$ & & & \\
\hline Significant & $=.000$ & & & \\
\hline$T_{\text {tabel }}$ & $=1,672$ & & & \\
\hline Source: Data processed, 2020. & &
\end{tabular}

The regression results obtained based on table 4.15 are as follows:

$Y=1,423+0,331 X 1+0,167 X 2+$ $0,284 \times 3+0,231 X 4+\mathrm{e}$

where:

Y : Government Agency Performance Accountability

$\mathrm{X} 1$ : HR Competencies

X2 : Internal Control System

X3 : Financial Report Quality

X4: Implementation of Government Accounting Standards

A: 1,423 is a constant number which means that if the free variables $X 1$, $X 2, X 3$ and $X 4$ are equal to zero, then the magnitude of variable $Y$ (accountability of government agency performance) is 1,423 . In other words, if variables are free of HUMAN RESOURCES competencies, internal control systems, the quality of financial statements and the application of government accounting standards are considered zero meaning the accountability of government agencies' performance will decrease by 1,423 .

B1: 0.331 is the magnitude of the coefficient of regression of free variables X1 HR competency which means that any increase (addition) of variable $\mathrm{X} 1 \mathrm{hr}$ competency will increase the variable bound $Y$ (accountability performance of government agencies) by 0.331 , assuming other free variables are constant. If the variable competency of human resources there is an increasing tendency of 0.331 then the performance accountability of government agencies will increase by 0.331 . If the human resources competency variable is in decline, then the accountability of government agencies' performance will also decrease.

B2: 0.167 is the magnitude of the coefficient of regression of free variables X2 internal control system which means any increase 
(addition) of variables $\mathrm{X} 2$ internal control system will increase the variable bound $Y$ (accountability performance of government agencies) by 0.167 , assuming other free variables constant. If the internal control system variable there is an increasing tendency to 0.167 then the accountability of the performance of government agencies will increase by 0.167 . If the variables of the internal control system are downward trend, then the accountability of government agencies' performance will also decrease.

B3: 0.284 is the magnitude of the coefficient of regression of free variables $\mathrm{X} 3$ quality financial statements which means any increase (addition) of variables X3 quality of financial statements will increase the variable bound $Y$ (accountability performance of government agencies) by 0.284 , assuming other free variables are constant. If the variable quality of financial statements there is an increasing trend of 0.284 then the performance accountability of government agencies will increase by 0.284 . If the variable quality of financial statements is in decline, then the accountability of government agencies' performance will also decrease.

B4: 0.231 is the magnitude of the coefficient of regression of free variables X4 the application of government accounting standards which means any increase (addition) of variables $\mathrm{X} 4$ the application of government accounting standards will increase the variable bound $Y$ (accountability performance of government agencies) by 0.231 , assuming other free variables are constant. If the variable implementation of government accounting standards there is an increasing trend of 0.231 then the performance accountability of government agencies will increase by 0.231 . If the variable implementation of government accounting standards is likely to decrease, then the accountability of government agencies' performance will also decrease.

\section{Hypothesis Test}

\section{a. Coefficient of Determination}

Coefficient determination test is used to test goodnes-fit and regression models. In this study the determinant coefficient test was used to see how much the independent variable was able to explain the dependent variable.

Table 12

Determination Coefficient Test Results

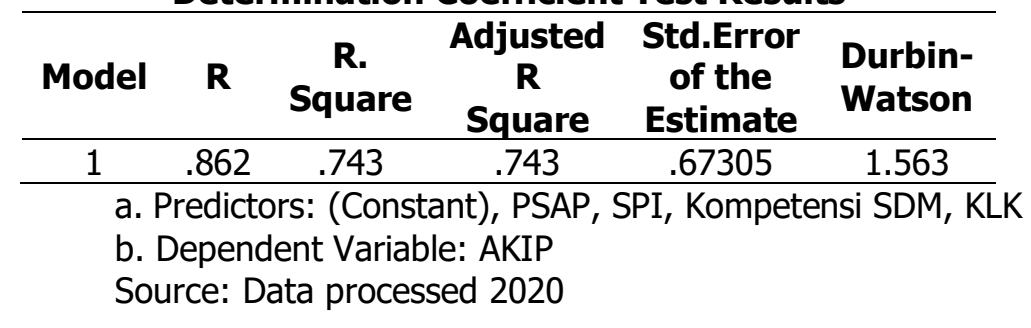

Based on the table 12, it can be known the magnitude of correlation coefficient $(R)$ of 0.862 which means that the correlation / relationship between human resources competency variables, control system quality of financial statements, and the application of government accounting standards in affecting the accountability of government agencies performance by $86.2 \%$ while adjust $R$ square value or coefficient of determination value of 0.723 which means that independent variables (HR competency, internal control system, quality of financial statements, and application of 
government accounting standards) are able to explain dependent variables (accountability of government agencies' performance) of $72.3 \%$ and the rest a of $27.7 \%$ can be explained by other factors outside of this study that were not studied by the authors.

\section{b. Test Statistics t}

This test can be done by looking at the $p$-value of each variable. If the $p$-value $<0.05$ then the hypothesis is accepted and if the $p$-value> 0.05 then the hypothesis is not supported (Ghozali, 2006).

Testing the relationship, used t test, namely by comparing the value of thitung with ttabel. Independent variables forming regression models are said to have a significant effect if thitung > ttabel or significant levels $<a=$ 0.05 . The results of the $t$ statistical test can be seen in the table below:

Table 13

Individual Parameter Test Results (t Test)

\begin{tabular}{cccccc}
\hline \multirow{2}{*}{ Model } & $\begin{array}{c}\text { Unstandardized } \\
\text { Coefficients }\end{array}$ & $\begin{array}{c}\text { Standardized } \\
\text { Coefficients }\end{array}$ & \multirow{2}{*}{ Sig. } \\
\cline { 2 - 5 } & $\mathbf{B}$ & $\begin{array}{c}\text { Std. } \\
\text { Error }\end{array}$ & Beta & & \\
\hline 1 (Constant) & 1.423 & .924 & & 1.540 & .130 \\
\hline HR Competencies & .331 & .080 & .813 & 4.115 & .000 \\
\hline SPI & .167 & .081 & .390 & 2.064 & .044 \\
\hline KLK & .284 & .110 & .798 & 2.590 & .012 \\
\hline PSAP & .231 & .070 & 1.145 & 3.319 & .002 \\
\hline
\end{tabular}

a. Dependent Variable: AKIP

Source: Data processed 2020

Using the help of softwer SPSS version 21.00 , obtained t test statistics on HR competency (X1) of 4,115 with a significance rate of 0.000 . The statistical value of the thitung test was greater than the ttabel $(4,115>1,672)$ and also significantly smaller than the $a=$ 0.05 . This test showed that Ha was accepted so that it can be concluded that hr competencies have a significant effect on the performance accountability of government agencies in the Regional Device Organization (OPD) in Pegunungan Bintang District.

The internal control system variable $\mathrm{t}$ test statistic (X2) was obtained at 2,064 with a significance rate of 0.044 . The statistical value of the test was greater than the ttabel $(2,064>$ 1,672 ) and also significantly smaller than the $a=0.05$. This test showed that $\mathrm{Ha}$ was accepted so that it can be concluded that the internal control system has a significant effect on the performance accountability of government agencies in the Regional Device Organization (OPD) in Pegunungan Bintang District.

Statistical test $t$ variable quality of financial statements (X3) obtained by 2,590 with a significance rate of 0.012 . The statistical value of the test was greater than the $1,672>(2,590)$ and was also significantly smaller than the $a=0.05$. This test shows that Ha was accepted so that it can be concluded that the quality of financial statements has a significant impact on the performance accountability of government agencies at the Regional Device Organization (OPD) in Pegunungan Bintang District.

Statistics $t$ variable test implementation of government accounting standards (X4) obtained by 3,319 with a significance rate of 0.002 . The statistical value of the thitung test was greater than the 
ttabel $(3,319>1,672)$ and also significantly smaller than the $a=$ 0.05 . This test shows that $\mathrm{Ha}$ is accepted so that it can be concluded that the implementation of government accounting standards has a significant effect on the accountability of the performance of the.

\section{B. Discussion}

1. The Effect of HUMAN RESOURCES Competency on Performance Accountability of Government Agencies in Regional Device Organizations (OPD) in Pegunungan Bintang District.

Based on the results of the data analysis, it is known that the value of statistic $\mathrm{t}$ test against $\mathrm{hr}$ competency variable (X1) is 4,115 with a significance level of 0.000 . This test showed that Ha was accepted so that it can be concluded that hr competencies have a significant effect on the performance accountability of government agencies in the Regional Device Organization (OPD) in Pegunungan Bintang District.

The results of this study are in line with the results of the (Mahardini \& Miranti, 2018) the results of his research showed that human resource competence positively affects the accountability of the performance of government agencies. Other research conducted by (Karsana \& Suaryana, 2017) demonstrate that human resource competence has a positive and significant effect on the accountability of the performance of government agencies.

2. Effect of Internal Control System on Performance Accountability of Government Agencies on Regional Device Organization (OPD) in Pegunungan Bintang District.

From the results of the data analysis, it is known that the test value of the system variable $t$ test statistics internal control (X2) was obtained by 2,064 with a significance rate of 0.044 . This test showed that Ha was accepted so that it can be concluded that the internal control system has a significant effect on the performance accountability of government agencies in the Regional Device Organization (OPD) in Pegunungan Bintang District.

The results of this study are in line with the results of the (Merawati1 \& Putra, 2015) that internal control systems have a significant impact on government Performance Accountability. Research (Holle, Salle, \& Sanggenafa, 2019) stated that the internal control system has a significant effect on the accountability of the performance of government agencies.

3. Effect of Financial Report Quality on Government Agency Performance Accountability on Regional Device Organization (OPD) in Pegunungan Bintang District

From the results of the data analysis, it is known that the value of $t$ statistical test against the quality variable of financial statements (X3) obtained t test statistics of 2,590 with a significance rate of 0.012 . This test shows that $\mathrm{Ha}$ was accepted so that it can be concluded that the quality of financial statements has a significant impact on the accountability of the performance of government agencies at the Regional Device Organization (OPD) in Pegunungan Bintang District.

This research is in line with research from (Fitriyani \& Herawati, 2019) stating that the Quality of Financial Statements has a significant impact on the Accountability of Government Performance. Other research conducted by (Budiantara, 2015) proving that government accounting standards affect the accountability of government performance.

4. Effect of Government Accounting Standards On Accountability of Government Agencies' Performance in Regional Device Organizations (OPD) in Pegunungan Bintang District.

From the results of the data analysis, it is known that the value of $t$ statistical test against the variable application of government accounting standards (X4) obtained t test statistics of 3,319 with a significance rate of 0.002 . This test shows that $\mathrm{Ha}$ was accepted so that it can be concluded that the application of government 
accounting standards significant impact on the performance accountability of government agencies in the Regional Device Organization (OPD) in Pegunungan Bintang District.

These results are in line with research (Fitriyani \& Herawati, 2019) which states that the implementation of accrual-based government accounting standards has a significant effect on the Performance Accountability of Government Agencies.

5. Effect of implementation of government accounting standards, Internal Control system, quality of financial statements and human resource competency on Performance Accountability of government agencies in Regional Device Organization (OPD) in Pegunungan Bintang District.

The results of the data analysis, known statistical test value $f$ to variable application of government accounting standards, internal control system, quality of financial statements and human resources competency to the accountability of the performance of government agencies obtained $f$ test statistics of 37,503 with a significance level of 0.000 . This test shows that $\mathrm{Ha}$ is accepted so that it can be concluded that the application of government accounting standards, internal control systems, quality of financial statements and human resource competencies affect the accountability of the performance of government agencies in the Regional Device Organization (OPD) in Pegunungan Bintang District. In addition, the result of the coefficient of determination ( $R$ Square) was obtained a relationship density value of 0.723 or $72.3 \%$. It means that the implementation of government accounting standards, internal control systems, quality of financial statements and human resource competencies are able to contribute greatly to the accountability of the performance of government agencies in the Regional Device Organization (OPD) in Pegunungan Bintang Regency.

\section{CONCLUSION}

HR competence has a significant effect on the performance accountability of government agencies in Regional Apparatus Organizations (OPD) in the Bintang Mountains Regency. The internal control system has a significant effect on the accountability of the performance of government agencies in Regional Apparatus Organizations (OPD) in the Bintang Mountains Regency. The quality of financial reports has a significant effect on the accountability of the performance of government agencies in Regional Apparatus Organizations (OPD) in the Bintang Mountains Regency. The application of government accounting standards has a significant effect on the accountability of the performance of government agencies in Regional Apparatus Organizations (OPD) in the Bintang Mountains Regency. The application of government accounting standards, internal control systems, quality of financial reports and human resource competencies affect the accountability of government agencies' performance in Regional Apparatus Organizations (OPD) in the Bintang Mountains Regency

\section{REFERENCES}

Budiantara, Nugraen dan M. (2015). Pengaruh Penerapan Standar Akuntansi Pemerintah Terhadap Kualitas Laporan Keuangan dan Implikasinya Terhadap Akuntabilitas Kinerja. Universitas Komputer Indonesia. Goggle Scholer

Fitriyani, Novita, \& Herawati, Helmi. (2019). Pengaruh Penerapan Standar Akuntansi Pemerintah Berbasis Akrual, Sistem Pengendalian Intern Dan Kualitas Laporan Keuangan Terhadap Akuntabilitas Kinerja Instansi Pemerintah (Studi Kasus Inspektorat Kabupaten Bengkulu Tengah). JAZ: Jurnal Akuntansi Unihaz, 2(2), 1935.Google Scholer

Ghozali. (2006). Aplikasi Analisis Multivariate dengan Program SPSS. Semarang: Badan Penerbit UNDIP. In Analisis Multivariate dengan Program SPSS.Google Scholer 
Halim. (2010). Dasar-Dasar Akuntansi Biaya Edisi 4. BPFE. Yogyakarta.Google Scholer

Holle, Vania Annissa, Salle, Agustinus, \& Sanggenafa, Mariolin. (2019). Pengaruh Penerapan Standar Akuntansi Pemerintahan Berbasis Akrual, Sistem Pengendalian Intern Dan Motivasi Kerja Terhadap Kualitas Laporan Keuangan (Studi Kasus Pada Organisasi Perangkat Daerah Provinsi Papua). Jurnal Akuntansi Dan Keuangan Daerah, 14(1), 16-35.Google Scholer

Jensen, Michael C. (1976). Theory of the firm: Managerial behavior, agency costs and ownership structure. Journal of Financial Economics, 3 (4), 305360.Google Scholer

Karsana, I. Wayan, \& Suaryana, I. Gusti Ngurah Agung. (2017). Pengaruh Efektivitas Penerapan Sap, Kompetensi Sdm, dan Spi Pada Kualitas Laporan Keuangan Pemerintah Kabupaten Bangli. E-Jurnal Akuntansi Universitas Udayana, 21(1), 643-670.Google Scholer

Latjandu, Imelda, Kalangi, Lintje, \& Tinangon, Jantje J. (2016). Faktor-Faktor yang Mempengaruhi Kualitas Laporan
Keuangan Pemerintah Daerah di Kabupaten Kepulauan Talaud. Accountability, 5(2), 98-109.Google Scholar

Mahardini, Nikke Yusnita, \& Miranti, Ade. (2018). Dampak Penerapan Standar Akuntansi Pemerintahan dan Kompetensi Sumber Daya Manusia pada Kualitas Laporan Keuangan Pemerintah Provinsi Banten Tahun Anggaran 2015. JAK (Jurnal Akuntansi) Kajian IImiah Akuntansi, 5(1), 22-32.Google Scholer

Merawati1, Luh Komang, \& Putra, I. Putu Mega Juli Semara. (2015). Kemampuan Pelatihan Pasar Modal Memoderasi Pengaruh Pengetahuan Investasi Dan Penghasilan Pada Minat Berinvestasi Mahasiswa. Jurnal IImiah Akuntansi Dan Bisnis, 10 (2).Google Scholer

Riantiarno, Reynaldi, \& Azlina, Nur. (2011). Factors Affecting Accountability of Performance of Government Agencies (Study on Regional Work Units of Rokan Hulu Regency). Pekbis Jurnal, 3 (3), 560-568.Google Scholar

Udoyono, Kodar. (2012). E-procurement dalam Pengadaan Barang dan Jasa untuk Mewujudkan Akuntabilitas di Kota Yogyakarta. Jurnal Studi Pemerintahan, 3(1).Google Scholer

\section{Copyright holder :}

Ramasoyan, Pascalina Van Sweet Sesa, Kurniawan Patma, Rudiawie Larasati (2021)

First publication right :

Journal of Social Science

This article is licensed under: 